\title{
Cerebroside Elicitor Confers Resistance to Fusarium Disease in Various Plant Species
}

\author{
Kenji Umemura, Shigeki Tanino, Tadako Nagatsuka, Jinichiro Koga, \\ Michiaki Iwata, Kenji Nagashima, and Yoshimiki Amemiya
}

First, second, and fifth authors: Agricultural \& Veterinary Research Labs, Meiji Seika Kaisha Ltd., 760, Morooka, Kohoku-ku, Yokohama 222-8567, Japan; third and fourth authors: Health \& Bioscience Labs, Meiji Seika Kaisha Ltd., 5-3-1, Chiyoda Sakado-shi, Saitama 3500289, Japan; and sixth and seventh authors: Laboratory of Plant Pathology, Faculty of Horticulture, Chiba University, 648, Matsudo, Matsudo-shi, Chiba 271-8510, Japan.

Accepted for publication 23 March 2004.

\begin{abstract}
Umemura, K., Tanino, S., Nagatsuka, T., Koga, J., Iwata, M., Nagashima, K., and Amemiya, Y. 2004. Cerebroside elicitor confers resistance to Fusarium disease in various plant species. Phytopathology 94:813-818.

In the rice blast fungus pathosystem, cerebroside, a compound categorized as a sphingolipid, was found in our previous study to be a non-racespecific elicitor, which elicits defense responses in rice. Here we describe that cerebroside $\mathrm{C}$ is produced in diverse strains of Fusarium oxysporum, a common soilborne agent of wilt disease affecting a wide range of plant species. In addition, some type of cerebroside elicitor involving cerebro-

copersicon esculentum), melon (Cucumis melo), and sweet potato (Ipomoea batatas) with cerebroside B resulted in resistance to infection by each pathogenic strain of $F$. oxysporum. Induction of pathogenesis-related genes and $\mathrm{H}_{2} \mathrm{O}_{2}$ production by treatment with cerebroside $\mathrm{B}$ were observed in tomato root tissues. The cerebroside elicitor showed no antifungal activity against $F$. oxysporum in vitro, indicating that the cerebroside elicitor activates defense mechanisms to confer resistance to Fusarium disease. These results suggest that cerebroside functions as a non-race-specific elicitor in a wide range of plant-phytopathogenic fungus interactions. Additionally, cerebroside elicitor serves as a potential biologically derived control agent.
\end{abstract} side A, B, or C was detected in other soilborne phytopathogens, such as Pythium and Botrytis. Treatment of lettuce (Lactuca sativa), tomato (Ly-

A study of similarities in the innate immune systems between plants and animals was recently completed (44). The innate immune system is defined as a battery of mechanisms serving as the line of first defense in response to pathogenic organisms. These defense mechanisms are initiated based on the discrimination between self and nonself in a host. In higher plants, the signal molecules of this event are assumed to be race-specific elicitors, which are encoded by pathogen avirulence $(a v r)$ genes $(43,47)$, or nonrace-specific elicitors, which are various chemical derivatives of phytopathogenic origin $(6,14,41,53)$. Avr gene products are recognized by receptor proteins that contain mostly nucleotide binding site/leucine-rich repeat (NBS-LRR) sequences, encoded by the corresponding plant disease resistance $(R)$ genes (38). These characteristic NBS-LRR sequences are homologous to certain animal gene products involved in apoptotic cell death (31). On the other hand, numerous pathogen-derived compounds, referred to as nonrace-specific elicitors, have been shown to activate plant defense responses in both host and nonhost plants $(5,36)$. This type of resistance to most phytopathogens is assumed to be the predominant form of disease resistance in plants. In the animal innate immune system, it has been shown that pathogen surfacederived molecules, called pathogen-associated molecular patterns (PAMPs), are recognized by the host to induce the expression of defense genes and the production of antimicrobial compounds $(1,46)$. It is clear that PAMPs include bacterial flagellin, fungal glucan, and chitin, which are regarded as non-race-specific elicitors in the plant kingdom $(21,51)$.

Corresponding author: K. Umemura; E-mail address: kenji_umemura@meiji.co.jp

Publication no. P-2004-0607-01R

(c) 2004 The American Phytopathological Society
Additional keywords: biocontrol, plant defense activator, probenazole.
In our previous reports, cerebrosides $\mathrm{A}, \mathrm{B}$, and $\mathrm{C}$, categorized as sphingolipids, have been isolated as novel elicitors found in a wide range of phytopathogens $(27,50)$. Treatment with cerebroside elicitor has been demonstrated not only to induce rice phytoalexins $(7,25,26,49)$ and pathogenesis-related (PR) proteins synthesis (32), but to confer disease resistance in rice plants to rice blast fungus in paddy fields (50). Furthermore, cerebroside elicitor has been demonstrated to activate defense signaling in rice cell suspension cultures and in rice plants $(45,48)$. Although sphingolipid is regarded as a structural component of many eukaryotic cell membranes, recent studies suggest the involvement of sphingolipids and their metabolites in signal transduction pathways of various cellular responses in mammalian cells $(10,18-20,42)$. Previously, we demonstrated that the elicitor activity of cerebroside and its derivatives depends on the structural specificity of sphingolipid in rice $(27,50)$. The function of sphingolipids in fungi remained unclear, until a recent report indicated that conversion of sphingolipid to glycosphingolipid by glucosyltranferase is essential for normal development in Aspergillus species (30). No assessment of the biological activity of sphingolipids in plants had been reported except for our own work; however, in a recent study sphingosine-1-phosphate derived from sphingolipid was demonstrated to be involved in the signal transduction pathway controlling guard cell turgor $(9,34)$.

We report herein that all tested strains of Fusarium oxysporum contained cerebroside $\mathrm{C}$. In addition to $F$. oxysporum, cerebroside elicitor was found in other soilborne pathogens. Treatment with cerebroside B resulted in enhanced disease resistance against the pathogenic $F$. oxysporum in lettuce, tomato, melon, and sweet potato. Furthermore, cerebroside elicitor induced the synthesis of PR genes and $\mathrm{H}_{2} \mathrm{O}_{2}$ production in tomato root tissues. These results suggest that cerebroside functions as a general elicitor in several plant species, and as a potential biologically derived control agent. 


\section{MATERIALS AND METHODS}

Microorganisms and qualitative analysis of cerebroside elicitor. Pythium graminicola IFO32996, Botrytis allii IFO9430, Glomerella cingulata IFO5257, and Sclerotium cepivorum IFO32367 were purchased from the Institute for Fermentation, Osaka (IFO), Japan. Each microorganism was cultured in a potato/ sucrose (PS) liquid medium containing potato extract (200 $\mathrm{g}$ of potato) and $20 \mathrm{~g}$ of sucrose per liter for 6 days at $25^{\circ} \mathrm{C}$. Following collection of mycelia, the cerebroside elicitor was analyzed in a qualitative manner as previously described (48).

Plant culture. Plants such as lettuce (Lactuca sativa $\mathrm{L}$. cv. Patriot, Nitounosan Seed Co. Ltd., Japan), tomato (Lycopersicon esculentum L. cv. Ponteroza, Takii Seed Co. Ltd., Japan), and melon (Cucumis melo L. cv. Amus, Nihon Engei Seisan, Japan) were sown in a plug-tray $(2.5 \times 2.5 \mathrm{~cm}$ cells). Plants were grown in a greenhouse at 13 to $28^{\circ} \mathrm{C}$ and used about 4 weeks after seeding, when they had the fourth leaf expanded. Seedlings of sweet potato (Ipomoea batatas L. cv. Benikomachi) were used as commercially available.

Inducing chemicals and their application. The cerebroside elicitor used in this study was purified as previously described (50). To enable comparison between cerebroside and another chemical inducer, lettuce plants were treated with probenazole (3allyloxy-1, 2-benzisothiazole-1, 1-dioxide; Oryzemate, Meiji Seika Kaisha Ltd., Japan), as previously reported (50). As a positive control, benomyl (Benlate) purchased from Dupont Kabushiki Kaisha, was applied to sweet potato plants in the field

TABLE 1. Cerebroside $\mathrm{C}$ in various strains of Fusarium oxysporum

\begin{tabular}{ll}
\hline Strains of F. oxysporum & Host plant \\
\hline F. oxysporum f. sp. lactucae isolate SB1-1 (race 1) & Lettuce \\
F. oxysporum f. sp. lactucae isolate F9501 (race 2) & Lettuce \\
F. oxysporum f. sp. lycopersici race J-1 & Tomato \\
F. oxysporum f. sp. lycopersici race J-2 & Tomato \\
F. oxysporum f. sp. melonis race 0 & Melon \\
F. oxysporum f. sp. melonis race 1 & Melon \\
F. oxysporum f. sp. cucumerinum & Cucumber \\
\hline
\end{tabular}

experiment. Glucosylceramide (GlcCer) was purchased from Funakoshi Pharmaceutical Ltd., Japan.

Cerebroside protection experiments. Cerebroside was applied to plants by a dipping treatment with solutions of various concentrations. To evaluate the efficacy of cerebroside against Fusarium disease, each plant was scored for disease symptoms according to the following scale: 0 , healthy leaves; 1 , lower leaves stunted and yellowing; 2, slight wilt (less than 20\% of leaves wilting); 3 , moderate wilt (20 to $50 \%$ of leaves wilting); 4 , serious wilt (more than $50 \%$ of leaves wilting); and 5, dead. Disease scores were converted to disease severity by the following formula: disease severity $=[(\mathrm{B} \times 1)+(\mathrm{C} \times 2)+(\mathrm{D} \times 3)+(\mathrm{E} \times 4)+(\mathrm{F} \times$ $5)] /($ total number of plants), where B, C, D, E, F, and G are the number of plants corresponding to scores 1, 2, 3, 4, and 5, respectively.

Strains of F. oxysporum were cultured in PS liquid medium for 7 days at $25^{\circ} \mathrm{C}$ and then added to a soil and bran (1:1) mixed medium in flasks. After incubation for 3 weeks at $28^{\circ} \mathrm{C}$, conidia was scored as a plating method, using Komada's Fusarium selection medium (28), and diluted to make an infested soil at a given density of the conidia. After cerebroside treatment, each plant was transplanted in a plastic pot $\left(350 \mathrm{~cm}^{3}\right)$ packed with each causal F. oxysporum-infested soil and kept in a greenhouse.

Field trial. Sweet potato seedlings (I. batatas cv. Benikomachi, weakly resistant to Fusarium stem rot in the field) were purchased from Zen-Noh, Japan. Randomized split plots were used. After water or cerebroside B or benomyl treatment for $24 \mathrm{~h}$, each seedling was transplanted to subplots consisting of three $10 \mathrm{~m}$ rows, spaced $80 \mathrm{~cm}$ apart on 18 May 2000 in the Meiji Seika Kaisha test fields in Kayama, Odawara, Kanagawa Prefecture. Around 15 seedlings were grown within the rows, about $70 \mathrm{~cm}$ apart. Initial disease symptoms of natural infection were observed on 25 May. To evaluate the disease rate, diseased plants were scored on 3 June.

Northern blot analysis. cDNA probes were synthesized by polymerase chain reaction (PCR) amplification of insert DNA in pET28b (Novagen, Madison, WI) using forward primer (5'CTTCTCGACGTCTCATATGAG-3') and reverse primer (5'GCTACCAACCAATGTGTTGGT-3') for $P R-1$ (accession no.<smiles>[R]N[C@H](COC(O)C1OCCC(O)C1O)[C@H](O)/C=C/CC/C=C(\C)CCCCCCCCCC</smiles><smiles>[R]C[C@H](O)/C=C/CCCCCCCCCCCC</smiles>

Cerebroside A

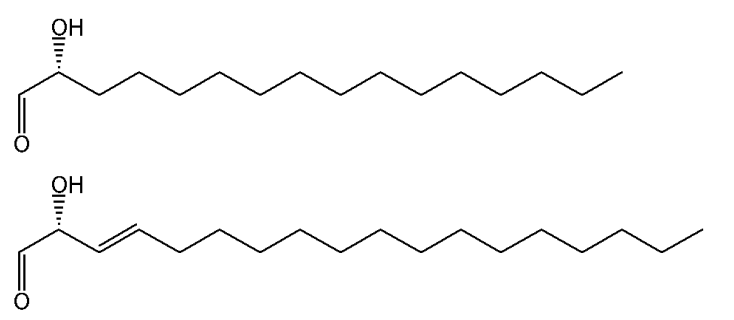

Cerebroside B

Cerebroside C

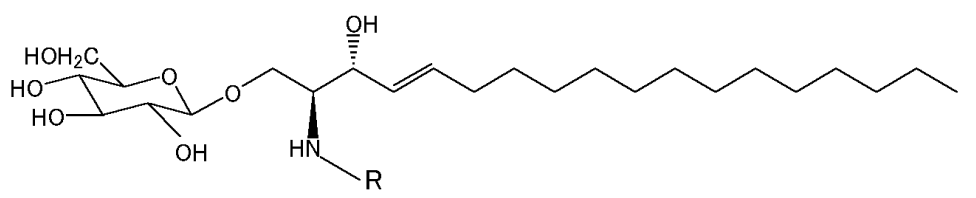

GlcCer
(from animal)

Fig. 1. Structures of cerebroside elicitor and animal-derived glucosylceramide (GlcCer). 
AI490182), and forward primer (5'-ACGTATATGGGGTCGTACTGGTT-3') and reverse primer (5'-TACATCCTCCAGGTACCTTAAGG-3') for PR-5 (accession no. AW034472). Total RNA was isolated from tomato roots by the Phenol/sodium dodecyl sulfate (SDS) method, as described elsewhere (2). Ten micrograms of total RNA was separated to formaldehyde gels, blotted onto Hybond-N membranes (Amersham Biosciences, Tokyo), hybridized to CDP-star (Amersham Biosciences) labeled probe, and fed to a CDP-star detection module according to the manufacturer's instructions. Equal loading was monitored by ethidium bromide staining of rRNA.

Measurement of $\mathrm{H}_{2} \mathrm{O}_{2}$ production. $\mathrm{H}_{2} \mathrm{O}_{2}$ production was followed by monitoring of the luminescent increase of MCLA (2methy-6-[p-methoxyphenol]-3,7-dihydroimidazo [1,2- $\alpha$ ]pyrazine3-one; Tokyo Kasei Kogyo, Tokyo). Five segments (1 cm length) of tomato roots were equilibrated in $0.1 \mathrm{M}$ phosphate buffer $(\mathrm{pH}$ 6.8), maintained in a spectrophotometer cuvette by mild agitation, and then mixed with a solution of MCLA at a final concentration of $0.3 \mathrm{mM}$. After addition of cerebroside at a given final concentration, MCLA luminescence was continuously measured with a luminescence reader (BLR-201; Aloka Co. Ltd., Japan) for 15 min, with 5-s intervals. Authentic $\mathrm{H}_{2} \mathrm{O}_{2}$ solution was used as a standard.

\section{RESULTS}

Cerebroside elicitor was found in diverse strains of $F$. oxysporum and in other soilborne pathogens, such as Pythium graminicola, Botrytis allii, Glomerella cingulata, and Sclerotium cepivorum. We sought to confirm the presence or absence of the cerebroside in mycelia of $F$. oxysporum, listed in Table 1, by thin-layer chromatography and reversed-phase high-performance liquid chromatography, as previously described (27). Cerebroside C (Fig. 1) was detected in the mycelia of all tested strains of $F$. oxysporum. Furthermore, some type of cerebroside elicitor was found in the mycelia of all soilborne pathogens examined, including $P$. graminicola, B. allii, $G$. cingulata, and $S$. cepivorum (Table 2). Cerebroside elicitors A, B, and C differ only in the lipid moiety (Fig. 1). Cerebroside elicitors have been shown to specifically induce the synthesis of phytoalexins and PR protein at the same concentrations in rice (50). The elicitor activity of cerebrosides in the case of rice plants has been shown to depend on the

TABLE 2. Cerebroside elicitors in diverse soilborne pathogens

\begin{tabular}{lc}
\hline Soilborne pathogens & Cerebroside species \\
\hline Pythium graminicola & $\mathrm{C}$ \\
Botrytis allii & $\mathrm{A}, \mathrm{B}$ \\
Glomerella cingulata & $\mathrm{B}$ \\
Sclerotium cepivorum & $\mathrm{B}$ \\
\hline
\end{tabular}

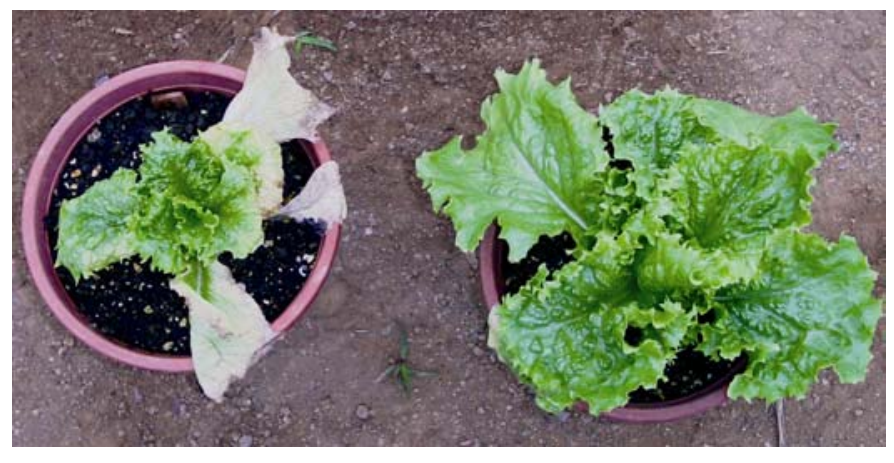

Fig. 2. Cerebroside-enhanced resistance to Fusarium disease of lettuce, control (left) and cerebroside treatment (right). Lettuce plants cultivated in plug-trays were treated with cerebroside B at $10 \mu \mathrm{g} / \mathrm{ml}$ for $24 \mathrm{~h}$ by dipping treatment or solvent $(0.5 \% \mathrm{EtOH})$. The disease symptoms were surveyed 13 days after transplanting into infected soil. structure of the sphingoid moiety characteristic of fungi, one example being the C-9 methyl group (27). Dickson and Lester (12, 13) reported that as in other sphingolipids, cerebroside is the essential component of the fungal cell membrane.

Cerebroside elicitor enhances resistance to Fusarium disease in various plant species. To determine whether cerebroside functions as an elicitor beyond the rice-blast interaction, cerebroside was tested for its potential to enhance resistance to Fusarium disease in various plant species. As shown in Figure 2, cerebroside B induced disease resistance to lettuce (Lactuca sativa cv. Patriot) by dipping treatment against the $F$. oxysporum f. sp. lactucae isolate SB1-1 (race 1) (16). Cerebroside C also enhanced disease resistance to root rot in lettuce (data not shown), indicating that its activity is equal to that of rice. The efficacy of cerebroside B was dose-dependent, and the application of cerebroside at concentration below $5 \mu \mathrm{g} / \mathrm{ml}$ resulted in reduced efficacy (Table 3). On the other hand, lettuce treated with probenazole (Oryzemate, Meiji Seika Kaisha) at $100 \mu \mathrm{g} / \mathrm{ml}$, considered to be a plant defense activator, showed slightly reduced disease development. The same phenomenon applied to inoculation with F. oxysporum f. sp. lactucae F9501 (race 2) as another isolate (data not shown). These results indicate that cerebroside elicitor is effective in controlling root rot caused by F. oxysporum f. sp. lactucae in lettuce.

Pretreatment with nonpathogenic $F$. oxysporum has been reported to reduce Fusarium disease in several plant species $(15,24$, 37 ). However, there seems to be no established theory to explain whether these microorganisms compete for nutrients with pathogenic microbes or enhance disease resistance in host plants. To determine whether cerebroside from the cell membrane of $F$. oxysporum is involved in one broad mechanism of action or the other, we tried to determine whether cerebroside enhanced resistance to Fusarium diseases in other plant species, as in lettuce. We observed the results of treating tomato (Lycopersicon esculentum $\mathrm{cv}$. Ponteroza) roots with cerebroside B at $10 \mu \mathrm{g} / \mathrm{ml} 2$ days before challenge inoculation with $F$. oxysporum f. sp. lycopersici race $\mathrm{J}-1$. As shown in Table 4, cerebroside B enhanced disease resis-

TABLE 3. Dose-dependency of cerebroside-enhanced resistance to Fusarium disease in lettuce (Lactuca sativa L. cv. Patriot)

\begin{tabular}{|c|c|c|c|c|}
\hline \multirow[b]{2}{*}{$\begin{array}{l}\text { Concentration } \\
(\mu \mathrm{g} / \mathrm{ml})\end{array}$} & \multicolumn{2}{|c|}{14 days postinoculation } & \multicolumn{2}{|c|}{28 days postinoculation } \\
\hline & $\begin{array}{l}\text { Disease } \\
\text { severity }^{a}\end{array}$ & $\begin{array}{c}\% \text { Diseased } \\
\text { plants }\end{array}$ & $\begin{array}{l}\text { Disease } \\
\text { severity }^{\mathrm{a}}\end{array}$ & $\begin{array}{c}\% \text { Diseased } \\
\text { plants }\end{array}$ \\
\hline Control & $1.2 \pm 1.2_{4}$ & 60 & $4.6 \pm 0.7_{3}$ & 100 \\
\hline 1 & $0.4 \pm 0.7_{2}$ & 30 & $1.9 \pm 1.5_{2}$ & 60 \\
\hline 5 & $0.3 \pm 0.4_{2}$ & 25 & $1.8 \pm 1.5_{2}$ & 60 \\
\hline 10 & $0_{1}$ & 0 & $0.6 \pm 1.0_{1}$ & 30 \\
\hline 20 & $0_{1}$ & 0 & $0.5 \pm 0.8_{1}$ & 30 \\
\hline $\begin{array}{l}\text { Probenazole } \\
\qquad(100 \mu \mathrm{g} / \mathrm{ml})\end{array}$ & $0.6 \pm 0.7_{3}$ & 25 & $4.3 \pm 0.9_{3}$ & 90 \\
\hline
\end{tabular}

a Mean value \pm standard deviation is based on two independent experiments encompassing 10 pots (one plant per pot). Inoculum density of Fusarium oxysporum f. sp. lactucae isolate $\mathrm{SB} 1-1$ (race 1) was measured at $2 \times$ $10^{5}$ conidia per gram of soil. The statistical significance of the values followed by various numbers in each column was determined using Duncan's multiple range test $(P=0.05)$.

TABLE 4. Cerebroside-enhanced resistance to Fusarium disease of tomato (Lycopersicon esculentum L. cv. Ponteroza) surveyed 21 days postinoculation

\begin{tabular}{lcc}
\hline Concentration & Disease severity $^{\mathrm{a}}$ & \% Diseased plants \\
\hline Control & $3.1 \pm 1.3_{2}$ & 93 \\
5 & $2.1 \pm 1.7_{1}$ & 68 \\
10 & $1.9 \pm 1.7_{1}$ & 70 \\
\hline
\end{tabular}

a Mean value \pm standard deviation is based on three independent experiments encompassing 20 pots (one plant per pot). Inoculum density of Fusarium oxysporum $\mathrm{f}$. sp. lycopersici race J-1 was measured at $2 \times 10^{4}$ conidia per gram of soil. The statistical significance of the values followed by various numbers was determined using Duncan's multiple range test $(P=0.05)$. 
tance in aerial parts of tomato compared with that of the untreated control. In the melon (C. melo cv. Amus) $-F$. oxysporum f. sp. melonis race 0 interaction, it was found that cerebroside $\mathrm{B}$ also enhanced disease resistance (Table 5). Therefore, it seems reasonable to conclude that cerebroside enhances Fusarium disease resistance in several plant species, and that cerebroside acts as a nonrace-specific elicitor in several plant $-F$. oxysporum interactions.

Cerebroside $B$ enhances resistance to Fusarium disease in sweet potato in the field. To examine the effects of cerebroside elicitor on resistance to Fusarium disease under practical conditions, cerebroside treatment was extended to the field. After seedlings of sweet potato (I. batatas cv. Benikomachi) were treated with cerebroside B for $24 \mathrm{~h}$, they were transplanted in $F$. oxysporum f. sp. batatas-infested soil (virulence factor not determined) for challenge-inoculation. As shown in Table 6, cerebroside effectively protected sweet potato from stem rot caused by $F$. oxysporum f. sp. batatas, as well as the fungicide benomyl. This indicates that cerebroside elicitor may have potential applications as a biologically produced control agent.

Cerebroside elicitor induces $\mathrm{PR}$ gene expression and $\mathrm{H}_{2} \mathrm{O}_{2}$ production in tomato plants. Earlier, we demonstrated that cerebroside treatment induces the expression of several PR proteins in rice plants (50). In the present study, we monitored the expression of genes coding for proteins of the PR-1 and PR-5 family in tomato root tissues by northern blot analysis. Accumulation of PR-1 mRNA was induced $48 \mathrm{~h}$ after cerebroside B dipping treatment (Fig. 3). As expected, no PR-1 mRNA induction was observed in control plants treated with water. GlcCer (Fig. 1), an animal-derived glycosphingolipid and an analogue of cerebroside, showed very weak PR-1 inducing activity, consistent with the lack of elicitor activity in rice, as described previously $(27,48)$. Expression of PR-5 mRNA was also induced by cerebroside treatment, although there was relatively low expression of this gene in both the water control and in GlcCer-treated roots. A few studies of the expression of PR proteins in tomato roots were examined $(8,35)$. The biological functions of these PR proteins in tomato roots remain uncertain, but cerebroside was demonstrated to induce their gene expression.

Cerebroside from fungal membrane components may participate in the initial step of plant-pathogen interactions. Rapid generation of active oxygen species involving $\mathrm{H}_{2} \mathrm{O}_{2}$ production is one of the earliest detectable defense reactions in plants. Thus, we

TABLE 5. Cerebroside-enhanced resistance to Fusarium disease of melon (Cucumis melo L. cv. Amus) surveyed 21 days postinoculation

\begin{tabular}{lccc}
\hline Concentration & $\begin{array}{c}\text { Number } \\
\text { of plants }\end{array}$ & Disease severity $^{\mathrm{a}}$ & $\begin{array}{c}\text { \% Diseased } \\
\text { plants }\end{array}$ \\
\hline Control & 30 & $1.6 \pm 1.5_{2}$ & 57 \\
10 & 23 & $0.4 \pm 1.0_{1}$ & 17 \\
20 & 25 & $0.5 \pm 1.1_{1}$ & 20 \\
\hline
\end{tabular}

${ }^{\text {a }}$ Mean value \pm standard deviation is based on two independent experiments encompassing 10 pots (one plant per pot). Inoculum density of Fusarium oxysporum f. sp. melonis race 0 was measured at $1 \times 10^{5}$ conidia per gram of soil. The statistical significance of the values followed by various numbers was determined using Duncan's multiple range test $(P=0.05)$.

TABLE 6. Cerebroside-enhanced resistance to Fusarium disease of sweet potato (Ipomoea batatas L. cv. Benikomachi) surveyed 16 days postinoculation

\begin{tabular}{lcc}
\hline Concentration & $\begin{array}{c}\text { Number of diseased } \\
\text { plants/healthy plants }\end{array}$ & \% Disease rate \\
\hline Control & $34 / 47$ & $72_{3}$ \\
20 & $10 / 44$ & $23_{2}$ \\
50 & $10 / 46$ & $22_{2}$ \\
Benomyl $(500 \mu \mathrm{g} / \mathrm{ml})$ & $7 / 47$ & $15_{1}$ \\
\hline
\end{tabular}

a The statistical significance of the values followed by various numbers was determined using Duncan's multiple range test $(P=0.05)$. tested whether cerebroside induced $\mathrm{H}_{2} \mathrm{O}_{2}$ production in tomato roots. As shown in Figure $4, \mathrm{H}_{2} \mathrm{O}_{2}$ production correlated with treatment with cerebroside in a dose-dependent manner. In agreement with the results of efforts to enhance disease resistance in lettuce, cerebroside $\mathrm{A}, \mathrm{B}$, and $\mathrm{C}$ showed the same specific activity in producing $\mathrm{H}_{2} \mathrm{O}_{2}$ in tomato roots (data not shown). Induction of $\mathrm{H}_{2} \mathrm{O}_{2}$ production in rice by cerebroside elicitor has already been reported by Suharsono et al. (45). These results suggest that cerebroside elicitor may function as a general determinant of nonself recognition by host plants in the early stages of several plantpathogen interactions.

\section{DISCUSSION}

This report indicates that cerebroside elicitor confers resistance to Fusarium diseases in various plant species. Cerebroside induced the expression of PR proteins in tomato plants and had no direct antifungal activity against $F$. oxysporum in vitro (data not shown), indicating that cerebroside activates plant defense mechanisms to confer resistance to Fusarium diseases. We also confirmed that cerebroside is produced by various species of $F$. oxysporum. Cerebroside functions as an elicitor in a wide range of plant $-F$. oxysporum interactions, in addition to the rice-blast fungus pathosystem. Moreover, cerebroside elicitor was found in a wide variety of phytopathogens, it appears that cerebroside from the cell membrane of phytopathogen is recognized by plants as a signal molecule of pathogen attack. These results suggest that cerebroside functions as an elicitor in many plant-pathogen interactions.

F. oxysporum is a soilborne parasite and an economically devastating agent of wilt disease in a wide range of plant species. Our field test demonstrated that cerebroside reduces Fusarium disease incidence on sweet potato even in an infested field. It has been proposed that application of elicitors can help control plant disease (4). This is based on the idea that pretreatment of a plant with elicitor molecules may sensitize the plant, allowing it to respond more rapidly to an actual pathogen infection. In our
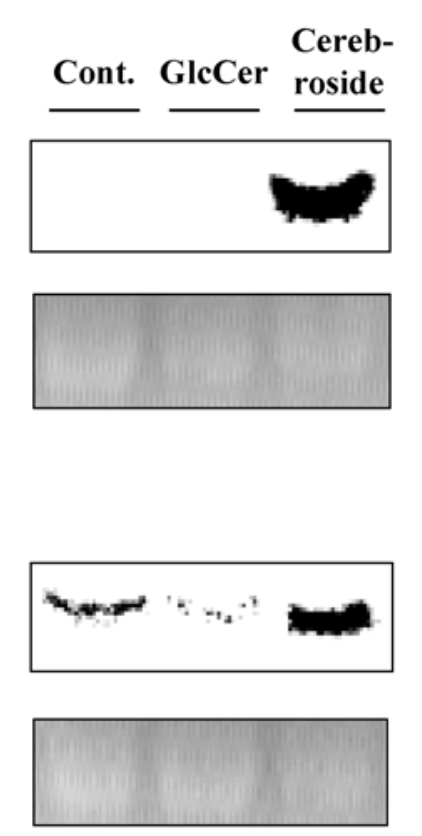

PR-1

\section{PR-5}

Fig. 3. Northern blot analysis of pathogenesis-related (PR) proteins induction in tomato roots. Tomato roots were treated by dipping with solvent $(0.5 \%$ EtOH: control) or glucosylceramide (GlcCer) solution $(10 \mu \mathrm{g} / \mathrm{ml})$ or cerebroside B solution $(10 \mu \mathrm{g} / \mathrm{ml})$. Total RNA was extracted from roots $48 \mathrm{~h}$ after sample treatment. Ten micrograms of total RNA was loaded per slot. The blot was developed with CDP-star module (Amersham Biosciences) using the probes indicated on the right. The experiment was carried out in triplicate with similar results. 
future work, we plan to develop cerebroside as a biologically produced control agent for agricultural use.

In this study, probenazole, considered a plant defense activator $(23,40)$, resulted in a slight reduction of disease development of $F$. oxysporum in lettuce. Probenazole is a chemical compound that has been used successfully for 30 years in Japan to protect rice plants against the rice blast fungus by inducing disease resistance in the field (54). Although cerebroside and probenazole have been demonstrated to share several common features, they appear to have different modes of action (50). Probenazole is a useful compound for analyzing signal pathways in plant defense mechanisms $(22,40,56)$. Cerebroside may also prove useful as a tool for improving our understanding of defense systems in plants (45).

Biological control of Fusarium disease with nonpathogenic strains of $F$. oxysporum has been studied in several plant species. Likewise, it has been reported that certain microorganisms also protects plants by inducing resistance. This biological-induced resistance was demonstrated in cases involving fungal root pathogens and cases involving fungal leaf pathogens $(39,52)$. Nevertheless, little is known about the molecular mechanisms involved in this bioprotection. In the current study, cerebroside elicitor was demonstrated to enhance resistance to soilborne Fusarium diseases. In earlier work with rice, we showed that cerebroside elicitor enhanced fungal foliar disease resistance (50). Therefore, it seems plausible that cerebroside elicitor is an important factor in this type of bioprotection.

In this report, cerebroside elicitor was demonstrated to induce the expression of PR proteins in tomato roots. PR-1 protein in tomato leaves has been reported to be involved in induced resistance $(8,35)$. However, it was demonstrated that accumulation of PR proteins in tomato roots is not always associated with bioprotection. It is unclear whether PR proteins belonging to the PR1 and PR-5 protein family are involved in the bioprotection of tomato roots (11), but cerebroside elicitor was demonstrated to induce the expression of PR proteins, as did infection by pathogens. On the other hand, GlcCer derived from an animal source

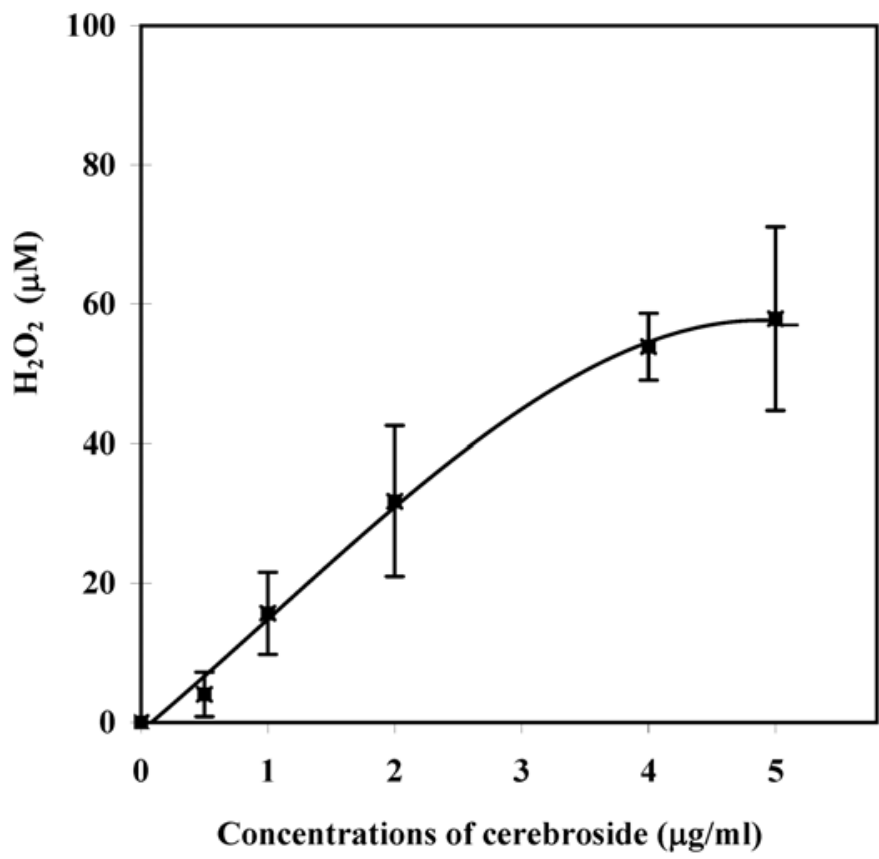

Fig. 4. Dose dependency of $\mathrm{H}_{2} \mathrm{O}_{2}$ production in tomato roots by cerebroside elicitor. Five segments $(1 \mathrm{~cm}$ length) of tomato roots were equilibrated in $0.1 \mathrm{M}$ phosphate buffer $(\mathrm{pH}$ 6.8) and then mixed with a solution of MCLA at a final concentration of $0.3 \mathrm{mM}$. Following addition of cerebroside $\mathrm{B}$ at given final concentration, MCLA luminescence was continuously measured using a luminescence reader for $15 \mathrm{~min}$, at 5-s intervals. The values shown are the mean and standard deviation of the results from four measurements. did not induce the expression of PR proteins in tomato roots, consistent with the lack of elicitor activity in rice. These results suggest that cerebroside represents a host-non-specific determinant of fungal recognition and several plant species possess a recognition system for cerebroside (55).

Rapid $\mathrm{H}_{2} \mathrm{O}_{2}$ production was reported to be an early response during interactions between plants and pathogens (29). There are two phases (phases I and II) in the kinetics of $\mathrm{H}_{2} \mathrm{O}_{2}$ production. A rapid and weak production of $\mathrm{H}_{2} \mathrm{O}_{2}$ (phase I) occurs after inoculation with either a virulent or an avirulent race of Pseudomonas syringae pv. glycinea in soybean cells (3). Phase II is a second and strong production of $\mathrm{H}_{2} \mathrm{O}_{2}$ in inoculation with an avirulent of Pseudomonas fluorescens but not a virulent strain (17). Therefore, it is proposed that phase I is a non-race-specific reaction, whereas phase II is responsible for race-specific disease resistance in plants. The second production phase of $\mathrm{H}_{2} \mathrm{O}_{2}$ in tomato roots after treatment with cerebroside was not observed until $10 \mathrm{~h}$ posttreatment (data not shown). Further experiments need to be performed to determine the function of cerebroside-induced $\mathrm{H}_{2} \mathrm{O}_{2}$ production in defense signaling.

In conclusion, our findings suggest that cerebroside elicitor may function as a nonspecific elicitor in many plant-fungus interactions as well as serving as a useful chemical for practical agronomic use.

\section{ACKNOWLEDGMENTS}

We thank M. Fujinaga and H. Ogiso (Nagano Vegetable and Ornamental Crops Experiment Station) for providing F. oxysporum f. sp. lactucae isolate SB1-1 (race 1) and isolate F9501 (race 2); Y. Amemiya (Faculty of Horticulture, Chiba University) for providing $F$. oxysporum $\mathrm{f}$. sp. lycopersici race $\mathrm{J}-1$ and $F$. oxysporum f. sp. cucumerinum; F. Namiki (National Agricultural Research Center for Kyushu-Okinawa Region) for providing F. oxysporum f. sp. melonis race 0 and race 1 (33); and our colleague, M. Matsumura (Meiji Seika Kaisha Ltd.), for technical support.

\section{LITERATURE CITED}

1. Aderem, A., and Ulevitch, R. 2000. Toll-like receptors in the induction of the innate immune response. Nature 406:782-787.

2. Ausubel, F. M., Brent, R., Kingston, R. E., Moore, D. D., Seidman, J. G., Smith, J. A., and Struhl, K. 1987. Current Protocols in Molecular Biology. John Wiley \& Sons, New York.

3. Baker, C. J., and Orlandi, E. W. 1995. Active oxygen in plant pathogenesis. Annu. Rev. Phytopathol. 33:299-321.

4. Benhamou, N. 1996. Elicitor-induced plant defence pathways. Trends Plant Sci. 1:233-240.

5. Boller, T. 1995. Chemoperception of microbial signals in plant cells. Annu. Rev. Plant Physiol. Plant Mol. Biol. 46:189-214.

6. Bostock, R. M., Kuc, J. A., and Laine, R. A. 1981. Eicosapentaenoic and arachidonic acids from Phytophthora infestans elicit fungitoxic sesquiterpenes in the potato. Science 212:67-69.

7. Cartwright, D., Langcake, P., Pryce, R. J., and Leworthy, D. P. 1977. Chemical activation of host defence mechanisms as a basis for crop protection. Nature 267:511-513.

8. Cohen, Y., Niderman, T., Mosinger, E., and Fluhr, R. 1994. $\beta$-Aminobutyric acid induces the accumulation of pathogenesis-related proteins in tomato (Lycopersicon esculentum L.) plants and resistance to late blight infection caused by Phytophthora infestans. Plant Physiol. 104:59-66.

9. Coursol, O., Fan, L.-M., Stunff, H. L., Sphiegel, S., Gilroy, S., and Assmann, S. M. 2003. Sphingolipid signaling in Arabidopsis guard cells involves heterotrimeric $G$ proteins. Nature. 423:651-654.

10. Cuvillier, O., Pirianov, G., Kleuser, B., Vanek, P. G., Coso, O. A., Gutkind, J. S., and Spiegel, S. 1996. Suppression of ceramide-mediated programmed cell death by sphingosine-1-phosphate. Nature 381:800-803.

11. Dassi, B., Dumas-Gaudot, E., and Gianinazzi, S. 1998. Do pathogenesisrelated (PR) proteins play a role in bioprotection of mycorrhizal tomato roots towards Phytophthora parasitica? Physiol. Mol. Plant Pathol. 52:167-183.

12. Dickson, R. C., and Lester, R. L. 1999. Metabolism and selected functions of sphingolipids in the yeast Saccharomyces cerevisiae. Biochim. Biophys. Acta 10:305-321.

13. Dickson, R. C., and Lester, R. L. 2002. Sphingolipid functions in Saccharomyces cerevisiae. Biochim. Biophys. Acta 1583:13-25. 
14. Ebel, J., and Cosio, E. G. 1994. Elicitors of plant defense responses. Int. Rev. Cytol. 148:1-35.

15. Fuchs, J. G., Moenne-Loccoz, Y., and Defago, G. 1997. Nonpathogenic Fusarium oxysporum strain Fo47 induces resistance to Fusarium wilt in tomato. Plant Dis. 81:492-496.

16. Fujinaga, M., Ogiso, H., Tuchiya, N., Saito, H., Yamanaka, S., Nozue, M., and Kojima, M. 2003. Race 3, a new race of Fusarium oxysporum f. sp. lactucae determined by a differential system with commercial cultivars. J. Gen. Plant Pathol. 69:23-28.

17. Glazener, J. A., Orlandi, E. W., and Baker, J. C. 1996. The active oxygen response of cell suspensions to incompatible bacteria is not sufficient to cause hypersensitive cell death. Plant Physiol. 110:759-763.

18. Hakomori, S. 1990. Bifunctional role of glycosphingolipids. J. Biol. Chem. 265:18713-18716.

19. Hannun, Y. A. 1994. The sphingomyelin cycle and the second messenger function of ceramide. J. Biol. Chem. 269:3125-3128.

20. Hannun, Y. A. 1996. Functions of ceramide in coordinating cellular responses to stress. Science 274:1855-1859.

21. Imler, J.-L., and Hoffman J. A. 2001. Toll-like receptors in innate immunity. Trends Cell Biol. 11:304-311.

22. Iwata, M. 2001. Probenazole: A plant defense activator. Pesticide Outlook $12: 28-31$

23. Iwata, M., Umemura, K., Teraoka, T., Usami, H., Fujisawa, Y., and Iwasaki, Y. 2003. Role of the $\alpha$ subunit of heterotrimeric G-protein in probenazole-inducing defense signaling in rice. J. Gen. Plant Pathol. 68:83-86.

24. Katsube, K., and Akasaka, Y. 1997. Control of Fusarium wilt of spinach by transplanting seedling pretreated with nonpathogenic F. oxysporum. (In Japanese with English summary) Ann. Phytopathol. Soc. Jpn. 63:389-394.

25. Koga, J., Ogawa, N., Yamauchi, T., Kikuchi, M., Ogasawara, N., and Shimura, M. 1997. Functional moiety for the antifungal activity of phytocassane E, a diterpene phytoalexin from rice. Phytochemistry 44:249-253.

26. Koga, J., Shimura, M., Oshima, K., Ogawa, N., Yamauchi, T., and Ogasawara, N. 1995. Phytocassanes A, B, C, D, novel diterpene phytoalexins from rice, Oryza sativa L. Tetrahedron 51:7907-7918.

27. Koga, J., Yamauchi, T., Shimura, M., Ogawa, N., Oshima, K., Umemura, K., Kikuchi, M., and Ogasawara, N. 1998. Cerebrosides A and C, sphingolipid elicitors of hypersensitive cell death and phytoalexin accumulation in rice plants. J. Biol. Chem. 273:31985-31991.

28. Komada, H. 1975. Development of a selective medium for quantitative isolation of Fusarium oxysporum from natural soil. Rev. Plant Prot. Res. 8:115-125.

29. Lamb, C., and Dixon, R. A. 1997. The oxidative burst in plant disease resistance. Annu. Rev. Plant Physiol. Plant Mol. Biol. 48:251-275.

30. Levery, S. B., Momany, M., Lindsey, R., Tiledo, M. S., Shayman, J. A., Fuller, M., Brooks, K., Doong, R. L., Straus, A. H., and Takahashi, H. K. 2002. Disruption of the glucosylceramide biosynthetic pathway in Aspergillus nidulans and Aspergillus funigatus by inhibitors of UDPGlc:ceramide glucosyltransferase strongly affects spore germination, cell cycle, and hyphal growth. FEBS Letts. 525:59-64.

31. Li, P., Nijhawan, D., Budihardjyo, I., Srinivasula, S. M., Ahmad, M., Alnemri, E. S., and Wang, X. 1997. Cytochrome c and dATP-dependent formation of Apaf-1/Caspase-9 complex initiates an apoptotic protease cascade. Cell 91:479-489.

32. Midoh, N., and Iwata, M. 1996. Cloning and characterization of a probenazole-inducible gene for an intracellular pathogenesis-related protein in rice. Plant Cell Physiol. 37:9-18.

33. Namiki, F., Shiomi, T., Nishi, K., Kayamura, T., and Tsuge, T. 1998. Pathogenic and genetic variation in the Japanese strains of Fusarium oxysporum f. sp. melonis. Phytopathology 88:804-810.

34. Ng, C. K., Carr, K., McAinsh, M. R., Powell, B., and Hetherington, A. M. 2001. Drought-induced guard cell signal transduction involves sphingosine-1-phosphate. Nature 410:596-599.

35. Niderman, T., Genetet, I., Bruyere, T., Gees, R., Stintzi, A., Legrand, M., Fritig, B., and Mosinger, E. 1995. Pathogenesis-related PR-1 proteins are antifungal. Plant Physiol. 108:17-27.
36. Nurnberger, T. 1999. Signal perception in plant pathogen defense. Cell Mol. Life Sci. 55:167-182

37. Ogawa, K., and Kodama, H. 1986. Fusarium wilt of sweet potato by nonpathogenic Fusarium oxysporum. (In Japanese with English summary) Ann. Phytopathol. Soc. Jpn. 52:15-21.

38. Pan, O., Wendel, J., and Fluhr, R. 2000. Divergent evolution of plant NBS-LRR resistance gene homologues in dicot and cereal genomes. J. Mol. Evol. 50:203-213.

39. Pieterse, C. M., van Wees, S. C., Hoffland, E., van Pelt, J. A., and van Loon, L. C. 1996. Systemic resistance in Arabidopsis induced by biocontrol bacteria is independent of salicylic acid accumulation and pathogenesis-related gene expression. Plant Cell 8:1225-1237.

40. Sekizawa, Y., Aoyama, H., Kimura, M., and Yamaguchi, I. 1995. GTPase activity in rice plasma membrane preparation enhanced by a priming effect for plant defense reactions. J. Pesticide Sci. 20:165-168.

41. Sharp, J. K., Valent, B., and Albersheim, P. 1984. The primary structures of one elicitor-active and seven elicitor-inactive hexa ( $\beta$-D-glucopyranosyl)-D-glucitols isolated from the mycelial walls of Phytophthora megasperma f. sp. glycinea. J. Biol. Chem. 259:11321-11336.

42. Simons, K., and Ikonen, E. 1997. Functional rafts in cell membranes. Nature 387:569-572

43. Staskawicz, B. J., Ausubel, F. M., Baker, B. J., Ellis, J. G., and Jones, J. D. G. 1995. Molecular genetics of plant disease resistance. Science 268:661-667.

44. Staskawicz, B. J., Mudgett, M. B., Dangl, J. L., and Galan, J. E. 2001. Common and contrasting themes of plant and animal diseases. Science 292:2285-2289.

45. Suharsono, U., Fujisawa, Y., Kawasaki, T., Iwasaki, Y., Satoh, H., and Shimamoto, K. 2002. The heterotrimeric G protein $\alpha$ subunit acts upstream of the small GTPase Rac in disease resistance of rice. Proc. Natl. Acad. Sci. USA 99:13307-13312.

46. Thoma-Uszynski, S., Stenger, S., Takeuchi, O., Ochoa, M. T., Engele, M., Sieling, P. A., Barnes, P. F., Rollinghoff, M., Bolcskei, P. L., Wagner, M., Akira, S., Norgard, M. V., Belisle, J. T., Godowski, P. J., Bloom, B. R., and Modlin, R. L. 2001. Induction of direct antimicrobial activity through mammalian Toll-like receptors. Science 291:1544-1547.

47. Tompson, J. N., and Burdon, J. J. 1992. Gene-for-gene coevolution between plants and parasites. Nature 360:121-125.

48. Umemura, K., Ogawa, N., Koga, J., Iwata, M., and Usami, H. 2002. Elicitor activity of cerebroside, a sphingolipid elicitor, in cell suspension cultures of rice. Plant Cell Physiol. 41:676-683.

49. Umemura, K., Ogawa, N., Shimura, M., Koga, J., Usami, H., and Kono, T. 2003. Possible role of phytocassane, rice phytoalexin, in disease resistance of rice against the rice blast fungus Magnaporthe grisea. Biosci. Biotechnol. Biochem. 67:899-902.

50. Umemura, K., Ogawa, N., Yamauchi, T., Iwata, M., Shimura, M., and Koga, J. 2000. Cerebroside elicitors found in diverse phytopathogens activate defense responses in rice plants. Plant Cell Physiol. 41:676-683.

51. Underhill, D. M., and Ozinsky, A. 2002. Toll-like receptors: Key mediator of microbe interaction. Curr. Opin. Immunol. 14:103-110.

52. van Wees, S. C., Pieterse, C. M., Trijssenaar, A., van't Westende, Y. A., Hartog, F., and van Loon, L. C. 1997. Differential induction of systemic resistance in Arabidopsis by biocontrol bacteria. Mol. Plant-Microbe Interact. 6:716-724.

53. Waspi, U., Blanc, D., Winkler, T., Ruedi, P., and Dudler, R. 1998 Syringolin, A novel peptide elicitor from Pseudomonas syringae pv. syringae that induces resistance to Pyricularia oryzae in rice. Mol. PlantMicrobe Interact. 11:727-733.

54. Watanabe, T., Igarashi, H., Matsumoto, K., Seki, S., Mase, S., and Sekizawa, Y. 1977. The characteristics of probenazole (Oryzemate) for the control of rice blast. J. Pesticide Sci. 2:291-296.

55. Worrall, D., Ng, C. K., and Hetherington, A. M. 2003. Sphingolipids, new players in plant signaling. Trends Plant Sci. 8:317-320.

56. Yoshioka, K., Nakashita, H., Klessig, D. F., and Yamaguchi, I. 2001. Probenazole induces systemic acquired resistance in Arabidopsis with a novel type of action. Plant J. 25:149-157. 